Jan., Feb., March, 1951

or other tid-bit offered by the robin. A few minuteslater the male oriole arrived and also fed the youngster. Thinking the male robin had fed the oriole by mistake, I was again surprised a few minutes later when the robin again fed the oriole, and I soon learned this was a regular performance. Next day the robin was seen numerous times feeding the oriole, sometimes on the ground and sometimes in the trees. The male oriole had, by this time, apparently left the vicinity for good, as neither the adults or young were seen again. Towards the evening I called in David and Alex Wright and their friend Bill Bradshaw, and together we watched the male robin feed the fledgling oriole as the two birds flew to a branch in a dead tree.

The young oriole was trapped and banded the second day out of the nest on July 17. By August 1st it had attained almost full growth, but still attended by and fed by the male robin. It was not seen after August 7 . The male robin remained until late September.

Northern Shrikes were quite numerous during part of November. These birds strike terror in the hearts of the hordes of English Sparrows to be seen about the grain el evators. Several shrikes will make large inroads in these flocks. However, English Sparrows are not the only small birds that fear the se predators. At my banding station recently, twn Black-capped Chickadees were seen to "freeze" as a Northern Shrike appeared in the neighborhood. Neither chickadee moved as much as a feather for 42 minutes, or until the shrike moved off. Their fear only can be estimated when one realizes how extremely difficult it must have been for these two busy little mites to remain still for such a long time and in 15 below zero weather.

Great destruction of our large beneficial hawks, such as the Red-tailed Hawk, by guns in the hands of thoughtless hunters and others is evident by the recovery of banded birds of this species banded at Nipawin. Of 20 Redtails banded since 1945, I have been informed by the United States Fish and

\section{Our Hearts are Still \\ On the Prairie}

It is a pleasure each January to receive the annual letter from one of the enthusiastic members of the Regina Natural History Society, who for the past few years has been living in Hamilton. Mrs. James Quigley writes in part;

"We greatly enjoy the BLUE JAY and pass it on to a member of the Nature Club to which we belong. She is eighty-three years young, never misses a meeting and is a real fan.

We had a delightful summer on the shore of Lake Ontario, near Trenton. The woods were beautiful from May to October and we had birds and flowers in abundance, also wild strawberries and good fishing.

But our hearts are still on the prairie. There is nothing to be compared with it -- we think so."

wildlife Service that 7 have been shot or killed in Saskatchewan and the States of ivisconsin, Iowa, Missouri, and Kansas. Also a single Redtail banded by Billy Matthews this past summer was killed at Neelin, Manitoba. Eight out of 21 , with others probably shot and not re ported.

An adult male Connecticut Warbler banded June 12th, 1950, is a first for this district -- the first I have ever seen. This species is very difficult to see as they keep to dense tangles and thickets, besides being quite rare.

On T. H. McL ellan's farm at Arcola, three coyotes were seen standing in the snow. They maintained their vigil so long that it was decided to investigate. They were frozen stiff -- the victims of 1080 poison. 